Natalia Koper

University College London

\title{
The Responsibility Dilemma The Role of the R2P in the U.S. Foreign Policy since the Rwanda Genocide
}

\begin{abstract}
This paper explores the role of the doctrine of the responsibility to protect (R2P) in shaping U.S. foreign policy in the post-Cold War period. Based on the in-depth study of declassified documents, public speeches, and other documents, this paper examines three case studies (Rwanda genocide, Iraq war, Libya conflict) as representative examples of the U.S. involvement in humanitarian crises abroad. The analysis reveals a consistently evolving narrative of a country fatalistically balancing the dilemma of responsibility. On the one side, having assumed the role of a global leader and norm-carrier, the United States is expected to act accordingly, and intervene in foreign humanitarian crises, safeguarding nations facing grave and continuous violations of human rights. On the other hand, every administration has been faced with the possibility of a backlash from either the public opinion, which does not prioritize humanitarian causes abroad, or the international community, which is not indifferent to violations of the principle of state sovereignty. As a result, the humanitarian narrative, albeit important, has been mainly applied as a secondary resource, and has not been the primary reason for interventions, as demonstrated with a number of inconsistencies in formulating foreign policies and employing the R2P rhetoric.
\end{abstract}

Key words: responsibility to protect, US foreign policy, humanitarian crisis, post-Cold War politics, mass atrocities crimes

In response to horrifying scenes from Syria broadcast by the mass media, only a few months after ascending to office, Donald Trump has urged "all civilized nations to join [the U.S.] in seeking to end the slaughter and bloodshed in Syria" ("President Trump's Syria strike statement..."), drastically altering his stance on the role of the U.S. to become involved in international interventions. In September 2013, for instance, he insisted that the exact opposite action would be appropriate for the U.S. "President Obama, do not attack Syria," he tweeted then. "There is no upside and tremendous downside. Save your 'powder' for another (and more important) day!" (Trump). The arguably impulsive decision to launch an air-strike in Syria in April 2017 might have questioned the continuity or stability of American foreign policy, given that it has raised questions over the balance between global aspirations 
- historically characteristic for the American politics - and the declared isolationism that the Trump administration encapsulated in the presidential campaign's slogan "America first." Nonetheless, whilst advocating international military actions in Syria, Trump has referred to both national security interests and humanitarian appeals, situating himself within the long tradition of the U.S. narrative legitimizing military interventions with humanitarian appeals. It indicates that even though Trump projects his administration in terms of an antiestablishment disruption, he paradoxically remains under the influence of the same line of continuity, embodied in the contentious search for balance between American values and national interests. For that reason, the analysis of the post-Cold War American policy can still offer valuable insight to the current political decision-making.

The present paper evaluates the place of the responsibility to protect $(R 2 P)$ in the U.S. human rights foreign policy since the Rwanda genocide, which served as the initial impulse for creating a collective response mechanism. The reflections gathered here hope to add to the scholarly discussion on whether the world's expectations for the U.S. to assume responsibility for maintaining peace in the post-Cold War world have been viable. There are a variety of factors that exacerbate the complexity of the issue, including the transitional position of the U.S. in the global architecture, the legitimacy of Western values, the disputable role of international law and external actors, the dynamic relationship between the domestic public opinion and the rhetoric of the decision-makers - both capable of pulling the strings of foreign policy-making etc.

Basing my hypothesis on the study of official policy documents, declassified archives, and public speeches, I will argue that the legacy of remorse over Clinton's decision to not-intervene in Rwanda has largely affected the U.S. approach towards humanitarian crises, and, consequently, has served to legitimize the principle of the R2P in the U.S. The feeling of guilt and liability has been further reinforced by the Iraq intervention. I will, however, demonstrate that ultimately the R2P framework has had more weight in building the narrative than in formulating foreign policy goals; thus, unveiling the salience of public opinion as illusory and the capacity of policy-makers to undertake contentious political maneuvers as even less accountable.

Far from aspiring to provide an exhaustive analysis of this complex issue, the present paper intends to examine the dynamics of the evolution of the R2P notion in U.S. politics. With this in mind, the primary motivation behind selecting particular case studies was their impact on shaping the voice of public opinion on humanitarian crises and the American role in maintaining global peace. As a result, I decided to support the argument with three case studies i.e., Rwanda genocide, Iraq war, and Libya conflict, each corresponding to a different presidency and representative of different phases in the evolution of the U.S. foreign policy.

\section{Mitigating Unpalatable Alternatives}

The R2P is an international norm first formulated in 2001 by the International Commission on Intervention and State Sovereignty (ICISS), and subsequently adopted in its limited version during the 2005 World Summit. The 2009 report on the R2P 
implementation divided the UN provisions into three pillars (UN General Assembly, Implementing the responsibility...): (a) the responsibility of "each individual State (...) to protect its populations from genocide, war crimes, ethnic cleansing and crimes against humanity"; (b) the commitment of international community to react in cases when a state "is incapable or unwilling" to provide appropriate security measures; and (c) the importance of timely and flexible reaction, including the prevention and post-conflict cooperation (UN General Assembly, Resolution... para. 138-40). Notwithstanding, the UN resolution evaded several of the ICISS recommendations from 2001 like refraining from exercising the veto right in the Security Council (UNSC), or allowing the possibility for a unilateral intervention outside the UN scope.

In broad terms, under international law, coercive international interference will not receive legitimization unless on the grounds of self-defense or following authorization by the UNSC in accordance with Chapter VII of the UN Charter. The mandate of the R2P relates to the latter exception (Byers 24). In a sense, it was conceived in response to the hopelessness towards mass atrocities occurring in other states, and constitutes a last-resort humanitarian aid measure. Tony Blair expressed this attitude in his speech defending the cause of the Iraq intervention:

It may well be (...) that (...) a regime can systematically brutalize and oppress its people and there is nothing anyone can do, when dialogue, diplomacy and even sanctions fail, unless it comes within the definition of a humanitarian catastrophe (...). This may be the law, but should it be? ("Full text: Tony Blair's speech").

Kofi Annan confronted this issue in the same spirit, asking:

(...) if humanitarian intervention is, indeed, an unacceptable assault on sovereignty, how should we respond to a Rwanda, to a Srebrenica - to gross and systematic violations of human rights that offend every precept of our common humanity? (34).

Although American politicians have assumed more caution in embracing a similar rhetoric, Obama's 2013 speech at the United Nations General Assembly echoed the concerns that had fueled the creation of the principle over a decade earlier:

We live in a world of imperfect choices. Different nations will not agree on the need for action in every instance, and the principle of sovereignty is at the center of our international order. But sovereignty cannot be a shield for tyrants to commit wanton murder, or an excuse for the international community to turn a blind eye to slaughter. (...) [S]hould we really accept the notion that the world is powerless in the face of a Rwanda or Srebrenica? ("Remarks by President Obama...").

This legal limitation of international law, addressed above, is a result of collision with the inviolability of state sovereignty, a fundamental principle regulating international politics. For this reason, the notion of the R2P, perceived by some states and scholars as a violation of the non-intervention principle (cf. Annan 34 para. 216) set forth in Articles 2.4 and 2.7 of the UN Charter, has created controversy. According to those provisions, states shall "refrain (...) from the threat or use of force against the territorial integrity or political independence of any state," as well as cannot 
"intervene in matters which are essentially within the domestic jurisdiction of any state" (UN Charter, Article 2, sec. 4 and 7).

Therefore, instead of undermining a basic norm, law-making bodies opted for adapting its interpretation to contemporary circumstances. The classical doctrine of sovereignty employed notions of national security and other vital interests to determine the boundaries of sovereignty (Bickerton et al.). On the other hand, the R2P was thought of as a protection mechanism not for the state itself, but for its population (Bellamy and Williams 826). In this way, the new norm bypassed restraints of international law in relation to absolute state sovereignty (Weiss, "RtoP alive and well..." 287), because it aimed at the safeguard of civilians, and not the overthrow of an oppressive regime. There are thus arguments supporting the view that the R2P solves rather than reinforces the paradox of sovereignty. For one thing, its purpose is to catalyze the sovereignty accountable to the international community; not to mention, it entails obligations instead of privileges (Deng et al.). And, most importantly, the $\mathrm{R} 2 \mathrm{P}$ adds human rights considerations to the definition of sovereignty, therefore expanding the clause on sovereignty from the 1933 Montevideo Convention ("Montevideo Convention..." Article 1).

The UNSC's failure to redeem itself after Rwanda puts the U.S. in a vulnerable position. Due to the incapacity to undertake a comprehensive internal reform, and a subsequent paralysis of this decision-making body, the UNSC displaced both the moral and the de facto responsibility to maintain the international status quo to the U.S., a country driven by the preexisting sense of moral global leadership, dating back to the origins of American exceptionalism. The value-based perspective on the R2P has been emphasized on numerous occasions:

To brush aside America's responsibility as a leader and (...) our responsibilities to our fellow human beings - Barack Obama claimed in the 2011 address to Libyans - (...) would have been a betrayal of who we are. Some nations may be able to turn a blind eye to atrocities in other countries. The United States of America is different. (...) I refused to wait for the images of slaughter and mass graves before taking action ("Remarks by the President...").

In this context, the U.S. stands before a dilemma: history has proven that the U.S.-led interventions are not well-received, but on the other hand, whenever the U.S. chooses to distance itself from a humanitarian crisis, it disappoints the international community that tacitly expected U.S. engagement. Hence, the answer for the deceptively simple question "who is responsible for international peace, and how to articulate this responsibility?" is suspended between two equally fatalistic extremes, or "unpalatable alternatives" (UN General Assembly, Implementing the responsibility... 6, para. 7): interventions "ha [ve] been controversial both when it happens, and when it has failed to happen" (ICISS 1).

\section{The Legacy of Failure}

In order to comprehend the current trends of the U.S. human rights policy, it is crucial to expand on its origin. The frequently criticized inaction of the West in light of the genocide in Rwanda has affected not only the UN system as a whole, but also its 
member states individually, especially the U.S. that built its image on a democracypromotion rhetoric.

From the outset of ethnic tensions in Rwanda, General Roméo Dallaire, who commanded the United Nations Assistance Mission for Rwanda (UNAMIR), repeatedly requested an urgent increase of troops for the UN mission. In a "genocide fax" to the UN headquarters dated to January 11, 1994, the Canadian General warned about a potential anti-Tutsi extermination plan (Dallaire). The U.S. stance on the issue was that UNAMIR was a peacekeeping, not peace-making operation; hence, U.S. officials favored a limited activity until the ceasefire would be secured (Klinghoffer 92). Ultimately, the mission was reduced from 2,500 to 270 peacekeepers (Byers 26).

Interestingly enough, declassified documents - a record of informal discussions within the UNSC - revealed that the main interest of the UNSC members was not the humanitarian crisis itself, but the safety of the UNAMIR personnel, or - in case of the U.S. administration - the evacuation of U.S. citizens and the downplay of the UN role in the region. Unofficially, the U.S. representatives stated that, "the Rwandan armed parties bore full responsibility for the continued violence and instability. The US did not believe that there was a role now in Rwanda for a United Nations peacekeeping force" (NSA 5-64 para. 7).

There was a visible discrepancy between Clinton's "assertive multilateralism" rhetoric from the beginning of his presidency and his approach from 1994 onwards. In his first speech to Congress in February 1993, he claimed that although economic competitiveness would be a main priority on his agenda, the U.S. "still ha[d] responsibilities," since it was "the world's only superpower." He acknowledged that global dangers and uncertainties such as ethnic cleansing and terrorism would require American engagement ("Address before a joint session of Congress"). Several months later, Clinton repeated those words in front of the UN Assembly, asserting that the U.S. would protect "the tide of freedom and democracy" from "the fierce winds of ethnic hatred" ("Address to the UN General Assembly").

Notwithstanding [the above], he changed the rhetoric unexpectedly in the aftermath of the Battle of Mogadishu, part of a U.S.-led Somali operation, that caused 18 U.S. casualties. ${ }^{1}$ Mogadishu was a culmination point that clarified the cost of world leadership for the American public. Immediately after the incident, Clinton ordered a six-month withdrawal procedure. The shadow of Somalia served to justify the U.S. reservations over involvement in Rwanda. "We should not abandon the Rwandan people, but we should also learn from the lessons of past operations," Madeleine Albright, Ambassador to the UN, allegedly said, during one of the informal UNSC meetings dedicated to Belgium's exit from Rwanda (NSA 5-30). Those reservations affected other domains of foreign policy as well. For instance, Clinton

1 The Battle of Mogadishu, fought on October 3-4, 1993 between the Somali militia and American forces, supported by the UN Operation in Somalia II, was part of the American Operation Gothic Serpent, aimed at capturing the leader of the militia Mohamed Farrah Aidid. The U.S. involvement in the Somali inter-clan conflict began a year before with a strictly humanitarian mandate to alleviate a severe famine in the country. At the same time, the UN began a peacekeeping operation with a mandate gradually extending, as the violence in Somalia spread. The military failure of the Mogadishu Battle, combined with the significant number of casualties, prompted strong criticism of the Clinton administration, which eventually led the president to announce the American withdrawal from the region (Rosenau 378-381). 
delayed military assistance in Bosnia despite previously having criticized George H.W. Bush administration's inaction in this regard (Apodaca 154).

The new policy, manifested in the Presidential Decision Directive (PDD 25) issued on May 3, 1994, specified the requirements for the U.S. to support a peacekeeping operation. The policymakers had to consider factors such as the international extent of peace threats, American interests and possible costs, the viability of objectives, exit strategy etc. ("Annex I"). PDD 25, published in the middle of Rwanda conflict, backed Clinton's cautious stance on the U.S. intervention. As a result, the range of global peacekeeping responsibility was radically limited to the interference only "to defend ourselves and our fundamental interests when they are threatened" (qtd. in "Clinton Optimistic About World Events").

At that time, the U.S. officials claimed that they had not received enough evidence of the atrocities to "fully appreciate the depth and the speed with which [Rwanda's people] were being engulfed by this unimaginable terror" (qtd. in Power, "Bystanders to genocide"). However, according to declassified documents of the U.S. State Department, the Clinton administration orchestrated a well-calculated campaign that downgraded the gravity of the crisis due to the political insignificance of Rwanda for Americans. The lack of political will to intervene was exposed in one of the Pentagon's memoranda which proves that the U.S. blocked the plan to jam the local hatred radio; unlike the "relief effort" perceived as a "wiser" choice, interfering the radio was "expensive and ineffective" (The Under Secretary of Defense. Memorandum... I-94/16544). Indeed, this explains the swift U.S. response to the last phase of the genocide, namely, assisting the crisis of refugees and displaced people in July 1994 (Burkhalter 44).

Even though some documents suggest that there was a debate within the State Department concerning the appropriate terminology regarding situation in Rwanda, statements of high-level Pentagon officials were vague, and avoided exaggerations. The murdered Tutsi population was referred to as "casualties," as if they were war combatants, and government officials were advised to mitigate public statements asserting that, "some acts of genocide may have occurred" rather than employing direct vocabulary (qtd. in Jehl). At its core, the rhetoric tactic followed the conviction that just as a state needs public support to launch a foreign military action, the public opinion should also approve of a state's decision to withhold from such an intervention. Labeling widespread and organized killings a "genocide," would have probably sensitized the public opinion to the situation, and obliged the U.S. government to undertake direct action. On this account, by employing rhetoric that distanced the Rwanda conflict from the language of a humanitarian crisis, the administration managed to delay the response of the public opinion. Interestingly, in this particular case, despite the importance of the nexus between the public narrative and the domestic audience, the role of the latter remained constrained to passively imposing boundaries on the acceptable rhetoric.

Clinton's failure to address the issue of humanitarian intervention in Rwanda demonstrates that the U.S. was not ready for the role it expected to assume in the post-Cold War world order. The incapacity to implement an effective foreign policy in Somalia that translated into the avoidance of solving the crisis in Rwanda undermined the U.S. credibility as a reliable global leader. Clinton's incoherence also signaled that the U.S. was experimenting a period of trial, testing different political 
masks for the new world order ball (Lewis). Regardless of what motivated it - fear of failure or genuine indifference - the dominating theme of the Clinton presidency was the absence of a political initiative, perceived by observers as a sign of "underachievement and squandered democracy" (Haass 136).

\section{Not on My Watch}

The self-confident "not on my watch," written by George W. Bush on the margin of the Rwanda genocide report, has become a symbol of the U.S. assuming the leading role in maintaining global peace. However clear a lesson it seemed at the beginning of the Bush administration, the highly criticized inaction of the Clinton administration towards the Rwanda conflict has not saved the following administration from averting similar mistakes. Since 1994, the prestige of the U.S. human rights foreign policy has been challenged by several crises, including the indifference to the Darfur crisis and power abuses in Iraq.

Unlike Clinton, however, George W. Bush knew exactly what kind of world leadership he sought for the U.S. Hiding weaknesses, fear, or indecision, Bush systemically built a narrative distancing himself from previous heads of state, what nurtured the opinion that his administration was "a reactive combination of calculations to avoid his father's mistakes and to reject Clinton's policies" (Blumenthal 796). He even implied it, while arguing in favor of an Iraq intervention a week before Congress put it to the vote: "[ $\mathrm{t}]$ he United Nations would betray the purpose of its founding and prove irrelevant to the problems of our time. And through its inaction, the United States would resign itself to a future of fear" ("Transcript..."). In fact, the strong image of U.S. leadership reflected governmental ratings considerably, and this dimension of interventions is relevant, if we agree with Samantha Power that, "it is in the realm of domestic politics that the battle to stop genocide is lost" (A Problem from Hell xviii). Following this logic, Bush's legitimacy increased substantially after $9 / 11$ from $44 \%$ support to $54 \%$ after, whilst the support of the federal government during the Rwanda genocide maintained at the level of approximately $20 \%$, compared with above- $40 \%$ results during the Iraq invasion in 2003 ("Public Trust in Government..."), which would indicate the American society disapproved of Clinton's handling the U.S. foreign policy more than of Bush's.

When it comes to Iraq, some scholars argue that the R2P has not played an important role there, for the humanitarian justification appeared ex post facto, when the plausibility of security threat discourse began to erode (e.g. Moses et al.). The narrative of a global security threat relied upon a set of frameworks, including the existence of weapons of mass destruction (WMD), Iraqi links with Al-Qaeda, the undemocratic regime of Saddam Hussein, Iraq's incompliance with international law as defying the credibility of the UN, the potential threat to regional stability (Moses et al. 354). The humanitarian dimension of the intervention was indeed less prevalent in this picture. In a 30 minute speech preceding the intervention, Bush expressed his concern over human rights abuses only once, stating vaguely that, "America believes that all people are entitled to hope and human rights, to the non-negotiable demands of human dignity. People everywhere prefer freedom to 
slavery, prosperity to squalor, self-government to the rule of terror and torture" ("Full text: George Bush's address").

Another aspect of the R2P studied in the context of Iraq is "the misappropriation" (Evans) and "manipulation" (Weiss, "Cosmopolitan force...") of the R2P language in the context of Bush's intentions. The weakness of the argument though lies in the fact that those authors erroneously emphasize the uncertainty of "real" intentions of the Bush administration, even though it is evidently a somewhat speculative factor. In fact, regardless of whether the moral rhetoric was intentional, false, or whether the notion of the R2P was introduced in the discourse, or whether the Iraq intervention complied with its premises, it undoubtedly influenced the debate on the R2P. As a matter of fact, the Iraq war is the most common case study in the analysis of the abuse of the R2P and humanitarian discourse, and for this reason, it is crucial to examine the relation between Iraq and sovereign responsibility. Paradoxically, in defiance of the Latin writ ex iniuria ius non oritur ("unlawful act does not lead to law") (Cassese), the misapplication of the R2P advanced its diffusion, for the controversy sparked a debate that led to clarifying the boundaries of the norm (Badescu and Weiss).

Although the R2P addresses the international dimension of state accountability, it does not at any point legitimize a unilateral intervention, and this is why it is believed that the White House misinterpreted the mandate of the R2P. Before the 2005 World Summit, the concept of the R2P was broadly criticized in the U.S., as America had been unwilling to assume new obligations under international law (Junk 537). The emergence of the R2P narrative, considered a liability at that time, was among the reasons for a delayed response towards Darfur (Junk 544; Jarvis 2013 226). However, it did not impede the White House from distorting the meaning of the R2P when it needed additional legitimization.

In contrast to Samantha Power's conviction about the importance of domestic legitimization, studies show that only half of Americans believe in the importance of defending human rights internationally, and only one third of the society believes that the promotion of democracy is a very important goal for the U.S. foreign policy. On the other hand, security has been the prevailing goal for Americans; over past decade the counter-terrorism and preventing proliferation of WMD have maintained support of over $80 \%$ ("In foreign affairs..."). This data suggests that the persistent humanitarian narrative assumed by Bush and his allies primarily targeted salience abroad.

Changing the semantics of intervention after failing to prove the validity of the security threat framework was a tactical move oriented at convincing the international community about the moral leadership of the U.S. As illustrated above, Bush did not truly enshrine the R2P doctrine; instead, he rather molded its scope, so that it would fit his narrative. Nonetheless, even though Bush did not fully satisfy the implicit promise hidden in his judgment on the Rwanda genocide, he demonstrated at least that America would not respond to global threats leniently, and in this sense he reinforced the notion of the U.S. as "the indispensable nation" (Zenko). 


\section{Setting an Example}

Over the course of the Obama presidency, it became evident that the commitment to the $\mathrm{R} 2 \mathrm{P}$ and mass atrocity prevention in general was elevated to a priority on the foreign policy agenda, demonstrated not only in Obama's official doctrine, but also in real institutional changes and undertaken actions. However, its endorsement as an international norm reinforced the pledge, on the U.S. foreign policy, to prevent mass atrocities even in cases in which the U.S. had no apparent national interests at stake, and for that reason, it inevitably exacerbated the domestic concerns that the R2P was a double-edged sword (Reinold). At the same time, Obama's diplomatic efforts to comply with the R2P promises through involvement in diverse humanitarian crises positively affected the credibility of the R2P among the international community, diminishing controversy over the potentially excessive application of the "humanitarian exception" (Bellamy, "Ethics and Intervention..."). This led the scholarship to believe that the Obama administration rather successfully confronted the infamous legacy of "inhumanitarian nonintervention" (Chesterman 54) and the allegations that the R2P is a "Trojan horse" of Western neo-imperialists (Bellamy, "Responsibility to protect or Trojan horse?...").

Obama's support for the R2P on the international arena had been preceded with the domestic implementation of a new doctrine. A year before the Libya intervention, the White House published the National Security Strategy, formulating the goals and priorities of American policy. The document contained explicit references to the R2P and pledged the U.S. to multilateral and bilateral cooperation against genocide and other mass violations of human rights (48). Likewise, the first Quadrennial Diplomacy and Development Review, a study of the U.S. diplomatic blueprints issued in January 2011, highlighted the need to "recognize the unique horror of genocide and mass atrocity, (...) to develop instruments to detect their threat, and (...) to develop structures and policies to ensure their prevention" (State Department 22). The document did not provide any details on those policies, but those later materialized as a palpable commitment to prevent genocide in the form of Presidential Decision Directive (PSD-10) following the Libya intervention, which brought the Atrocities Prevention Board into being. Nevertheless, the interagency initiative has been criticized ever since due to its lack of transparency (Wolf).

The Libya intervention was a culminating moment for implementing the R2P internationally. Firstly, Resolution 1973 from March 17, 2011, by calling upon “to take all necessary measures" and by enforcing a no-fly zone to protect Libyan civilian population, channeled a genuine embodiment of the R2P doctrine. Its textbook adoption was driven by the state failure to prevent the escalation of gross human rights violations, lack of political will of Libyan authorities to end the violence, and threats to international security (UNSC, Resolution 1973). The decision to react was "timely and flexible," considering the sudden and unexpected nature of the violence (Bellemy and Williams 838). Qaddafi had been given several opportunities to impede the intervention - including a warning Resolution 1970 and a personal call from the UN Secretary-General. This demonstrates that even though the U.S. was gradually accepting the implementation of the R2P, coercive measures were considered a last resort. Furthermore, it was the first resolution openly adopted against the consent of the local government (Bellamy, "Libya and the responsibility 
to protect..." 263-264), which is an application of the new contingent understanding of sovereignty. This, however, has attracted criticism that the presence of external actors reproduces quasi-colonial and paternalist relations between the North and South (e.g. Doyle and Sambanis; Cunliffe, Critical perspectives), and represents "the usurpation of self-determination" (Cunliffe, "From ISIS to ICISS..." 5).

It has been argued that Obama's decision to endorse the language of the R2P is partly a response to the mixed legacy of Bush. Bush's "war on terror" discredited the U.S. international role as "norm carrier" (Bellamy, "Responsibility to protect or Trojan horse?..." 32) due to the unilateral nature of U.S. policies and numerous abuses and violations of fundamental human rights by American soldiers abroad. In order to restore the image of a global leader - constituting "inescapable responsibility and unparalleled opportunity" (State Department 19) - Obama appealed to core American values, and reinstated them in the center of the U.S. foreign policy. Along with traditional American values such as civil liberties, democracy, exceptionalism etc., Obama invoked multilateral cooperation, so that "the burden of action" would "not be America's alone" ("Remarks by the President..."), and - more importantly aimed to reconstruct American identity (Jarvis). In an evident opposition to Bush Jr., Obama's presidency focused on reframing the unilateralism into the ideal of "liberal exemplarism," ${ }^{2}$ portrayed U.S. as the only model for other nations (Jarvis 225).

Concurrently, Obama paradoxically incorporated some aspects of the neoconservative language of the previous administration, balancing the multilateral expectations of the international community with the domestic inclination towards the focus on national interests. For instance, in the Presidential Study Directive from 2011, Washington appealed to the importance of both America's international image ("America's reputation suffers, and our ability to bring about change is constrained, when we are perceived as idle in the face of mass atrocities and genocide") and the pursuit of national security interests through international means ("Our security is affected when masses of civilians are slaughtered, refugees flow across borders, and murderers wreak havoc on regional stability and livelihoods"). It is worth emphasizing that the essence of Obama's policy-making was not directed at justifying a humanitarian intervention akin to Bush's narrative, but instead, by contributing to the international debate on appropriate responses to mass killings, Obama meant to uphold the country's international image of a collaborative leader.

Libya intervention is, however, far from a model for the future R2P application. Evaluating himself, Obama has recently acknowledged that the "worst mistake" of his tenure was "probably failing to plan for the day after what I think was the right thing to do in intervening in Libya" (qtd. in "Barack Obama says..."). In general, some argue that what failed was the framework of the R2P post-conflict assistance, because the premise of "shared responsibility" (Stahn 120) ultimately diluted the

2 The notion of "liberal exemplarism" refers to the debate arguably dating back to the origins of the first colonies and that has ever since dominated discussions on America's moral obligations to the rest the world. The term, coined by $\mathrm{H}$. W. Brands, represents the opinion that the American model of society and its values should serve as an example to be imitated by other nations, akin to the premises behind the famous "city on a hill" proclamations of John Winthrop in 1630. On the opposite side of the spectrum, Brands identified the "vindicationist" approach, according to which the U.S. should undertake proactive measures to assure the advance of American values internationally (Brands). 
responsibility (Cunliffe, "From ISIS to ICISS..."). Also, reconstructing a nation after a serious conflict is a long and vulnerable process, which is why the involvement of an external actor in local politics poses a substantial risk to boundaries between developmental aid and pursuing a political agenda. "Exit is about more than just the withdrawal of an external military and administrative presence" (Zaum 334), and the challenges of political transition in a post-conflict scenario - like transferring capabilities to domestic actors or building communication between opposing fractions - have proven to be an arduous task.

\section{Final Considerations}

As presented in this paper, the stance on international responsibility differed substantially depending on the president. The world seen through the lens of Clinton did not coincide with the neo-conservative filter of the Bush tenure or the multilateral optimism of Obama. Nonetheless, the post-Cold War U.S. foreign policy has been consistent when it comes to the rhetorical use of the humanitarian narrative, applied whenever all other justifications had failed or expired. Even the Nobel-winning Obama, who was desperately trying to reverse the damaging legacy of Bush's arrogance, did not, in the end manage to escape criticism over the outcomes of the Libya intervention. Furthermore, all three presidents have been condemned for acting with double standards. Clinton intervened in Somalia, yet stayed indifferent for Rwanda; Bush did not hesitate to pursue an attack in Iraq and Afghanistan, yet he acted reluctantly towards the crisis in Darfur; Obama supported an intervention in Libya, yet his involvement in Syria has contributed to an ongoing mass refugee exodus.

Taking everything into consideration, there is some evidence indicating that the emergence of the R2P has significantly affected the shape of U.S. foreign policy, even if it has served mainly as a reinforcement of the already established goals. Until the recent leadership change in the White House, the continuation of this trend would have seemed inevitable, especially in light of serious capacity challenges and the lack of operational preparedness of otherwise alternative peacekeeping bodies such as the UN. Ultimately, although the direction of the U.S. foreign policy under the Trump administration still remains inconsistent, the U.S. policy-makers must bear in mind that, whichever path they choose to follow, the legitimizing leverage offered by the R2P doctrine is also and foremost an obligation that, as a result, makes the American "exemplarism" accountable to the international community.

\section{References:}

Annan, Kofi. We the Peoples: The Role of the UN in the 21 ${ }^{\text {st }}$ Century. United Nations Department of Public Information, 2000. Web. August 1, 2017. www.un.org/en/events/pastevents/ pdfs/We_The_Peoples.pdf.

Apodaca, Clair. Understanding U.S. human rights policy: A paradoxical legacy. New York: Routledge, 2006.

Badescu, Cristina G., Weiss, Thomas G. "Misrepresenting R2P and Advancing Norms: An Alternative Spiral?" International Studies Perspectives. Vol. 11, No. 4, 2010: 354-374. http:/ / doi.org/10.1111/j.1528-3585.2010.00412.x 
"Barack Obama says Libya was 'worst mistake' of his presidency." The Guardian, April 12, 2016. Web. August 1, 2017. www.theguardian.com/us-news/2016/apr/12/barack-obama-says -libya-was-worst-mistake-of-his-presidency.

Bellamy, Alex J. "Ethics and Intervention: The 'Humanitarian Exception' and the Problem of Abuse in the Case of Iraq." Journal of Peace Research. Vol. 41, No. 2, 2004: 131-147.

Bellamy, Alex J. "Responsibility to protect or Trojan horse? The crisis in Darfur and humanitarian intervention after Iraq." Ethics \& International Affairs. Vol. 19, No. 2, 2005: 31-54.

Bellamy, Alex J. "Libya and the responsibility to protect: the exception and the norm." Ethics E International Affairs. Vol. 25, No. 3, 2011: 263-269.

Bellamy, Alex J., Williams, Paul D. "The new politics of protection? Côte d'Ivoire, Libya and the responsibility to protect." International Affairs. Vol. 87, No. 4, 2011: 825-850.

Bickerton, Christopher J., Cunliffe, Philip, Gourevitch, Alexander. Politics Without Sovereignty: A Critique of Contemporary International Relations. London and New York: University College London Press, 2007.

Blumenthal, Sidney. The Clinton Wars. New York: Farrar, Strauss, and Giroux, 2003.

Brands, H.W. What America Owes the World: The Struggle for the Soul of Foreign Policy. New York: Cambridge University Press, 1998.

Burkhalter, Holly J. "The question of genocide: The Clinton administration and Rwanda." World Policy Journal. Vol. 11, No. 4, 1994: 44-54.

Byers, Michael. "International law and the responsibility to protect." [in:] Chinkin, Christine, and Baetens, Freya (ed.). Sovereignty, Statehood and State Responsibility. Cambridge UK: Cambridge University Press, 2015: 23-50.

Cassese, Antonio. “Ex Iniuria Ius Oritur: Are We Moving Towards International Legitimation of Forcible Humanitarian Countermeasures in the World Community?" European Journal of International Law. Vol. 10, No. 1, 1999: 23-30.

Chesterman, Simon. "Hard Cases Make Bad Laws: Law, Ethics, and Politics in Humanitarian Intervention." [in:] Lang, Anthony F. (ed.). Just intervention. Washington DC: Georgetown University Press, 2003: 46-61.

"Clinton Optimistic About World Events: Presidency: Reflecting on D-day, he says he is upbeat about the future despite 'ragged edges and uncertainties.'" Los Angeles Times, May 29, 1994. Web. August 1, 2017. www.articles.latimes.com/1994-05-29/news/mn-63685_1 _ragged-edges.

Clinton, William Jefferson. "Address before a joint session of Congress on Administration goals." The public papers of the president, February 27, 1993. Web. August 1, 2017. Web. presidency.ucsb.edu/ws/?pid=47232.

Clinton, William Jefferson. "Address to the UN General Assembly." $48^{\text {th }}$ Session of the General Assembly, New York, September 27, 1993. Web. August 1, 2017. www.2009-2017.state. gov/p/io/potusunga/207375.htm.

Cunliffe, Philip. "From ISIS to ICISS: A critical return to the Responsibility to Protect report." Cooperation and Conflict. Vol. 51, No. 2, 2015: 233-247. https://doi.org/10.1177/00 10836715612854.

Cunliffe, Philip (ed.). Critical Perspectives on the Responsibility to Protect: Interrogating Theory and Practice. London and New York: Routledge, 2011.

Dallaire, Roméo. Shake Hands with the Devil: The Failure of Humanity in Rwanda. Toronto: Random House Canada, 2003.

Deng, Francis M., Kimaro, Sadikiel, Lyons, Terrence, Rothchild, Donald, Zartman, I. William. Sovereignty as Responsibility: Conflict Management in Africa. Washington: Brookings Institution Press, 1996.

Doyle, Michael W., Sambanis, Nicholas. Making War and Building Peace: United Nations Peace Operations. Princeton NJ: Princeton University Press, 2006.

Evans, Gareth. The Responsibility to Protect: Ending Mass Atrocity Crimes Once and for All. Washington: Brookings Institution Press, 2008. 
"Full text: George Bush's address on the start of war." The Guardian, March 20, 2003. Web. August 1, 2017. www.theguardian.com/world/2003/mar/20/iraq.georgebush.

"Full text: Tony Blair's speech." The Guardian, March 5, 2004. Web. August 1, 2017. www.theguardian.com/politics/2004/mar/05/iraq.iraq.

Haass, Richard N. “The Squandered Presidency: demanding more from the Commander-in-Chief." Foreign Affairs. Vol. 79, No. 3, 2000: 136-140.

ICISS (International Commission on Intervention and State Sovereignty). The Responsibility to Protect. Report of the International Commission on Intervention and State Sovereignty. International Development Research Centre, December 2001. Web. August 1,2017. www.responsibilitytoprotect.org/ICISS\%20Report.pdf.

"In foreign affairs, Americans are less receptive to moral arguments." Pew Research Center, September 6, 2013. Web. August 1, 2017. www.pewresearch.org/fact-tank/2013/09/06/ in-foreign-affairs-americans-are-less-receptive-to-moral-arguments/.

Jarvis, Samuel A. “Obama's Adoption of the Responsibility to Protect: A Constructivist Analysis." Journal of Politics \& International Studies. Vol. 9, 2013: 212-249.

Jehl, Douglas. "Officials Told to Avoid Calling Rwanda Killings 'Genocide.'” New York Times, June 10, 1994: A8.

Junk, Julian. "The two-level politics of support - US foreign policy and the responsibility to protect." Conflict, Security \& Development. Vol. 14, No. 4, 2014: 535-564.

Klinghoffer, Arthur. The International Dimension of Genocide in Rwanda. Basignstoke: Macmillan, 1998.

Lewis, William H. “'Assertive Multilateralism': Rhetoric vs. Reality.” McNair Paper: Peacekeeping: The Way Ahead. No. 24-25, 1993: 13-28.

"Montevideo Convention on the Rights and Duties of States." International Conference of American States, Montevideo, Uruguay, December 26, 1933.

Moses, Jeremy, Bahador, Babak, Wright, Tessa. "The Iraq War and the Responsibility to Protect: Uses, Abuses and Consequences for the Future of Humanitarian Intervention." Journal of Intervention and Statebuilding. Vol. 5, No. 4, 2011: 347-367.

NSA (National Security Archives). United Nations Security Council Informal Session Notes: April-June 1994. Web. August 1, 2017. www.nsarchive.gwu.edu/ageofgenocide/Volume $\% 202 \% 20$ (pgs\%201-100).pdf.

Obama, Barack. "Nobel Lecture: A Just and Lasting Peace." Oslo, December 10, 2009.

Obama, Barack. "Remarks by President Obama in Address to the United Nations General Assembly." White House, September 24, 2013. Web. August 1, 2017. www.obama whitehouse.archives.gov/the-press-office/2013/09/24/remarks-president-obamaaddress-united-nations-general-assembly.

Obama, Barack. "Remarks by the President in Address to the Nation on Libya." White House, March 28, 2011. Web. August 1, 2017. www.obamawhitehouse.archives.gov/thepress-office/2011/03/28/remarks-president-address-nation-libya.

Power, Samantha. "Bystanders to genocide." Atlantic Monthly. Vol. 288, No. 2, 2001: 84-108.

Power, Samantha. "A Problem from Hell": America and the Age of Genocide. New York: Perennial, 2003.

"President Trump's Syria strike statement in full." BBC News, 7 April 2017. Web. February 16, 2018. www.bbc.com/news/world-us-canada-39524274.

“Public Trust in Government: 1958-2017." Pew Research Center, May 3, 2017. Web. August 1, 2017. www.people-press.org/2017/05/03/public-trust-in-government-1958-2017/.

Reinold, Theresa. "The United States and the Responsibility to Protect: Impediment, Bystander, or Norm Leader?" Global Responsibility to Protect. Vol. 3, No. 1, 2011: 61-87. Web. August 1, 2017. www.theatlantic.com/magazine/archive/2001/09/bystanders-to-geno cide/304571/.

Rosenau, William G. “'Every Room Is a New Battle': The Lessons of Modern Urban Warfare.” Studies in Conflict \& Terrorism. Vol. 20, No. 4, 1997: 371-394. 
Stahn, Carsten. "R2P and Jus Post Bellum." [in:] Stahn, Carsten, Easterday, Jennifer S., Iverson, Jens (ed.). Jus Post Bellum. Mapping the Normative Foundations. Oxford: Oxford University Press, 2014: 102-123.

State Department. "The First Quadrennial Diplomacy and Development Review." United States Department of State, 2010. Web. August 1, 2017. www.state.gov/documents/or ganization/153108.pdf.

Thakur, Ramesh. "Iraq and the Responsibility to Protect." Behind the Headlines. Vol. 62, No. 1, 2004: 1-16.

The Under Secretary of Defense. Memorandum for Deputy Assistant to the President for National Security Affairs, National Security Council I-94/16544, May 5 1994. Web. August 1 , 2017. www.nsarchive.gwu.edu/NSAEBB/NSAEBB53/rw050594.pdf.

"Transcript: George Bush's speech on Iraq." The Guardian, October 7, 2002. Web. August 1, 2017. www.theguardian.com/world/2002/oct/07/usa.iraq.

Trump, Donald (@realDonaldTrump), “President Obama, do not attack Syria. There is no upside and tremendous downside. Save your 'powder' for another (and more important) day!" [Twitter], Sep. 7, 2013. Web. August 1, 2017. www.twitter.com/realDonaldTrump/ status/375577511473983488?ref_src=twsrc\%5Etfw\&ref_url=https\%3A\%2F\%2Fwww.ny times.com \%2F 2017\%2F04\%2F07\%2Fus \%2Fpolitics\%2Fdonald-trump-syria-twitter.html.

UN Charter. Charter of the United Nations and Statute of the International Court of Justice. United Nations, Office of Public Information, 1945.

UN General Assembly. Resolution adopted by the General Assembly. 2005 World Summit Outcome. UN resolution, A/RES/60/1, 2005. Web. August 1, 2017. www.un.org/women watch/ods/A-RES-60-1-E.pdf.

UN General Assembly. Implementing the responsibility to protect: Report of the Secretary-General. UN document A/63/677, 12, 2009. Web. August 1, 2017. www.un.org/rule oflaw/files/SG_reportA_63_677_en.pdf.

UNSC (United Nations Security Council). Resolution 1973. S/RES/1973, March 17, 2011. Web. August 1, 2017. www.un.org/ga/search/view_doc.asp?symbol=S/RES/1973\%20 $\% 282011 \% 29$.

Weiss, Thomas G. "Cosmopolitan force and the responsibility to protect. Roundtable: humanitarian intervention after 9/11." International Relations. Vol. 19, 2004: 211-250.

Weiss, Thomas G. "RtoP alive and well after Libya." Ethics $\mathcal{E}$ International Affairs. Vol. 25, No. 3, 2011: 287-292.

White House. Presidential Decision Directive 25. US Policy on Reforming Multilateral Peace Operations, May 3, 1994. Web. August 1, 2017. www.fas.org/irp/offdocs/pdd/pdd-25. pdf.

White House. National Security Strategy of the United States. DIANE Publishing, 2010. Web. August 1, 2017. www.nssarchive.us/NSSR/2010.pdf.

White House. Presidential Study Directive on Mass Atrocities/PSD-10. August 4, 2011. Web. August 1, 2017. www.obamawhitehouse.archives.gov/the-press-office/2011/08/04/ presidential-study-directive-mass-atrocities.

Wolf, Amelia M. "Why Is Obama Suppressing the Atrocities Prevention Board?" The National Interest, August 27, 2014. Web. August 1, 2017. www.nationalinterest.org/feature/ why-obama-suppressing-the-atrocities-prevention-board-11152.

Zaum, Dominik. "Jus Post Bellum and the Politics of Exit." [in:] Stahn, Carsten, Easterday, Jennifer S., Iverson, Jens (ed.). Jus Post Bellum. Mapping the Normative Foundations. Oxford: Oxford University Press, 2014: 334-346.

Zenko, Micah. "The Myth of the Indispensable Nation." Foreign Policy, November 6, 2014. Web. August 1, 2017. www.foreignpolicy.com/2014/11/06/the-myth-of-the-indispen sable-nation/. 